\title{
Nitrate source identification in the Baltic Sea using its isotopic ratios in combination with a Bayesian isotope mixing model
}

\author{
F. Korth ${ }^{1, *}$, B. Deutsch ${ }^{2}$, C. Frey ${ }^{1}$, C. Moros ${ }^{1}$, and M. Voss ${ }^{1}$ \\ ${ }^{1}$ Leibniz Institute for Baltic Sea Research Warnemünde, Seestr. 15, 18119 Rostock, Germany \\ ${ }^{2}$ Baltic Sea Centre, Stockholm University, 10691 Stockholm, Sweden \\ * now at: GEOMAR Helmholtz-Centre for Ocean Research, Wischhofstrasse 1-3, 24148 Kiel, Germany \\ Correspondence to: F. Korth (frederike.korth@io-warnemuende.de)
}

Received: 25 March 2014 - Published in Biogeosciences Discuss.: 24 April 2014

Revised: 7 July 2014 - Accepted: 8 August 2014 - Published: 15 September 2014

\begin{abstract}
Nitrate $\left(\mathrm{NO}_{3}^{-}\right)$is the major nutrient responsible for coastal eutrophication worldwide and its production is related to intensive food production and fossil-fuel combustion. In the Baltic $\mathrm{Sea} \mathrm{NO}_{3}^{-}$inputs have increased 4-fold over recent decades and now remain constantly high. $\mathrm{NO}_{3}^{-}$source identification is therefore an important consideration in environmental management strategies. In this study focusing on the Baltic Sea, we used a method to estimate the proportional contributions of $\mathrm{NO}_{3}^{-}$from atmospheric deposition, $\mathrm{N}_{2}$ fixation, and runoff from pristine soils as well as from agricultural land. Our approach combines data on the dual isotopes of $\mathrm{NO}_{3}^{-}\left(\delta^{15} \mathrm{~N}_{-} \mathrm{NO}_{3}^{-}\right.$and $\left.\delta^{18} \mathrm{O}-\mathrm{NO}_{3}^{-}\right)$in winter surface waters with a Bayesian isotope mixing model (Stable Isotope Analysis in R, SIAR). Based on data gathered from 47 sampling locations over the entire Baltic Sea, the majority of the $\mathrm{NO}_{3}^{-}$in the southern Baltic was shown to derive from runoff from agricultural land (33-100\%), whereas in the northern Baltic, i.e. the Gulf of Bothnia, $\mathrm{NO}_{3}^{-}$originates from nitrification in pristine soils (34-100\%). Atmospheric deposition accounts for only a small percentage of $\mathrm{NO}_{3}^{-}$levels in the Baltic Sea, except for contributions from northern rivers, where the levels of atmospheric $\mathrm{NO}_{3}^{-}$are higher. An additional important source in the central Baltic Sea is $\mathrm{N}_{2}$ fixation by diazotrophs, which contributes $49-65 \%$ of the overall $\mathrm{NO}_{3}^{-}$pool at this site. The results obtained with this method are in good agreement with source estimates based upon $\delta^{15} \mathrm{~N}$ values in sediments and a three-dimensional ecosystem model, ERGOM. We suggest that this approach can be easily modified to determine $\mathrm{NO}_{3}^{-}$sources in other marginal seas or larger near-coastal areas where $\mathrm{NO}_{3}^{-}$is abundant in winter surface waters when fractionation processes are minor.
\end{abstract}

\section{Introduction}

Throughout the world, anthropogenic reactive $\mathrm{N}$ currently exceeds natural production (Galloway et al., 2003; Gruber and Galloway, 2008). Consequently, riverine nitrogen (N) fluxes have doubled in recent years, which has strongly impacted the marine $\mathrm{N}$ cycle and ecosystem health, both at regional and global scales. In coastal ecosystems, the adverse effects of these excess $\mathrm{N}$ loads include eutrophication, hypoxia, loss of biodiversity, and habitat destruction (Galloway et al., 2003; Villnäs et al., 2013). For the shallow, brackish, semi-enclosed Baltic Sea, where intense anthropogenic nutrient loadings have been documented since the 1950s (Elmgren, 2001), riverine and atmospheric nutrient inputs are now at least 4-fold higher than a century ago, when anthropogenic influence was low (Schernewski and Neumann, 2005; Stålnacke et al., 1999). Furthermore, cyanobacterial blooms, which can fix $\mathrm{N}_{2}$, and thus add nutrients to the surface waters are regular large scale phenomenon each summer (Finni et al., 2001; Vahtera et al., 2007) and the overall increase in nutrient input has supported the expansion of hypoxic zones (Conley et al., 2009, 2011).

A main component of the $\mathrm{N}$ pool and the one most readily available is nitrate $\left(\mathrm{NO}_{3}^{-}\right)$(Nestler et al., 2011; Vitousek et al., 1997), which derives from a wide variety of sources. These can be identified by analysis of the $\mathrm{N}$ and oxygen (O) isotopes $\left(\delta^{15} \mathrm{~N}_{-} \mathrm{NO}_{3}^{-}\right.$and $\left.\delta^{18} \mathrm{O}-\mathrm{NO}_{3}^{-}\right)$since the isotopic ratios of $\mathrm{NO}_{3}^{-}$from different sources fall within distinct ranges (Kendall, 1998; Kendall et al., 2007). For example, $\mathrm{NO}_{3}^{-}$inputs from forested catchments can be discriminated from those coming from agricultural runoff, and the $\mathrm{NO}_{3}^{-}$ 


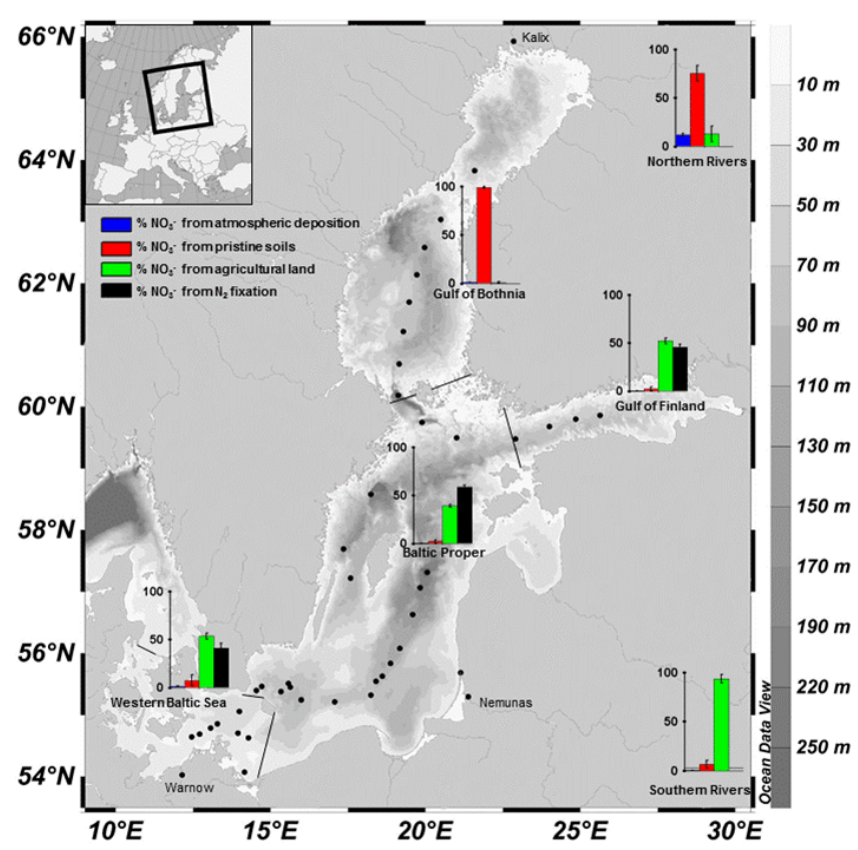

Figure 1. Station Map of the Baltic Sea and percent contribution of the four nitrate sources, $\mathrm{NO}_{3}^{-}$from atmospheric deposition (blue), pristine soils (red), agricultural runoff (green), and $\mathrm{N}_{2}$ fixation (black), for the Western Baltic Sea, Baltic Proper, Gulf of Finland, Gulf of Bothnia, southern rivers, and northern rivers. Stations are indicated as black dots. For more details see Supplement Table 1.

signature of microbial nitrification differs from that of atmospheric deposition (Kendall, 1998; Kendall et al., 2007; Mayer et al., 2002). Source attribution is, however, complicated by $\mathrm{N}$-transformation processes such as denitrification, nitrification, and assimilation, each of which gives rise to significant isotope fractionation. Since heavier isotopes are sequestered more slowly than lighter ones, the reaction product will be isotopically depleted compared to the original $\mathrm{NO}_{3}^{-}$source (Kendall, 1998). Alterations of isotope values because of microbial fractionation processes can be minimized by collecting the samples in winter, when low water temperatures reduce microbial activity (Pfenning and McMahon, 1997).

Nonetheless, source attribution is still complicated when there are more than three sources but only two isotopes that describe them (Fry, 2013). SIAR (Stable Isotope Analysis in R), a Bayesian isotope mixing model originally developed to infer diet composition from the stable isotope analysis of samples taken from consumers and their food sources (Moore and Semmens, 2008), was already successfully applied for $\mathrm{NO}_{3}^{-}$source identification. Xue et al. (2012, 2013) were able to estimate the proportional contributions of five potential $\mathrm{NO}_{3}^{-}$sources in a small watershed in Flanders (Belgium). Based on their determinations of the isotopes of nitrogen and oxygen they could show that manure and sewage were the major sources of $\mathrm{NO}_{3}^{-}$.
Table 1. $\mathrm{NO}_{3}^{-}$concentrations and $\delta^{15} \mathrm{~N}-\mathrm{NO}_{3}^{-}$and $\delta^{18} \mathrm{O}-\mathrm{NO}_{3}^{-}$values of wet atmospheric deposition. Data are from Warnemünde (Germany), Sännen (Sweden), and Majstre (Sweden).

\begin{tabular}{|c|c|c|c|c|}
\hline Location & Date & $\begin{array}{r}\mathrm{NO}_{3}^{-} \\
\left(\mu \mathrm{mol} \mathrm{L}{ }^{-1}\right)\end{array}$ & $\begin{array}{r}\delta^{15} \mathrm{~N}-\mathrm{NO}_{3}^{-} \\
(\% \circ)\end{array}$ & $\begin{array}{r}\delta^{18} \mathrm{O}-\mathrm{NO}_{3}^{-} \\
(\% \circ)\end{array}$ \\
\hline Warnemünde & 21 Dec 2009 & 52.7 & 2.1 & 75.6 \\
\hline Warnemünde & 4 Jan 2010 & 51.2 & 1.1 & 68.3 \\
\hline Warnemünde & 19 Jan 2010 & 104.4 & 0.2 & 84.6 \\
\hline Warnemünde & 1 Feb 2010 & 50.8 & 0.8 & 65.8 \\
\hline Warnemünde & 19 Feb 2010 & 94.4 & 0.6 & 79.5 \\
\hline Warnemünde & 22 Feb 2010 & 106.8 & 2.1 & 81.8 \\
\hline Sännen & Dec 2009 & 12.1 & -0.3 & 69.2 \\
\hline Sännen & Jan 2010 & 60.4 & -1.1 & 81.8 \\
\hline Sännen & Feb 2010 & 69.3 & -2.1 & 77.0 \\
\hline Majstre & Dec 2009 & 30.7 & -0.8 & 83.8 \\
\hline
\end{tabular}

In the Baltic Sea the $\mathrm{NO}_{3}^{-}$pool present in the surface waters in spring originates from the previous growth season and is consumed during the onset of the phytoplankton spring bloom, in February/March. Stratification in summer hinders circulation down to the halocline, thus atmospheric deposition and $\mathrm{N}_{2}$ fixation are the major $\mathrm{N}$ sources, whereas in coastal areas riverine discharge dominates (Radtke et al., 2012; Voss et al., 2011). Yet, to what extent the various $\mathrm{NO}_{3}^{-}$ sources add to the overall pool of $\mathrm{NO}_{3}^{-}$in the Baltic as a whole is still a matter of debate. In this study, a source attribution for four major sources is presented. Taking the Baltic Sea as an example we will show, that the use of the isotopic composition of $\mathrm{NO}_{3}^{-}\left(\delta^{15} \mathrm{~N}_{-} \mathrm{NO}_{3}^{-}\right.$and $\left.\delta^{18} \mathrm{O}-\mathrm{NO}_{3}^{-}\right)$in combination with SIAR can be used elsewhere for source identification on an ecosystem scale level.

\section{Material and methods}

\subsection{Field sampling}

Surface water samples from the Baltic Sea were collected in February $2008(n=22)$ and $2009(n=17)$ before the onset of the phytoplankton spring bloom aboard the RV Alkor and in November $2011(n=1)$ aboard the RV Meteor using a Seabird CTD system with attached water bottles. Samples from the Nemunas River $\left(55^{\circ} 18^{\prime} 5.5 \mathrm{~N}, 21^{\circ} 22^{\prime} 53.9 \mathrm{E}\right.$; $\left.55^{\circ} 41^{\prime} 25.6 \mathrm{~N}, 21^{\circ} 7^{\prime} 58.4 \mathrm{E} ; n=4\right)$ and the Kalix River $\left(65^{\circ} 56^{\prime} 4.2 \mathrm{~N}, 22^{\circ} 53^{\prime} 9.2 \mathrm{E} ; n=1\right)$ (Fig. 1) were taken between November 2009 and February 2010. Values for $\mathrm{NO}_{3}^{-}$ in which atmospheric deposition was the source were obtained from wet deposition samples collected at three stations around the Baltic Sea: Warnemünde, Germany $\left(54^{\circ} 10^{\prime} \mathrm{N}\right.$, $12^{\circ} 5^{\prime} \mathrm{E}$,); Majstre, Sweden $\left(57^{\circ} 30^{\prime} \mathrm{N}, 18^{\circ} 31^{\prime} \mathrm{E}\right)$; and Sännen, Sweden $\left(56^{\circ} 13^{\prime} \mathrm{N}, 15^{\circ} 17^{\prime} \mathrm{E}\right)$ from December 2009 until February 2010 (Table 1). In Warnemünde, precipitation was collected on an event basis, and retrieved daily to limit microbial degradation, using a sampler consisting of a plastic funnel (diameter: $24 \mathrm{~cm}$ ) connected to a $1 \mathrm{~L}$ polyethylene 
Table 2. Means and standard deviations of the $\delta^{15} \mathrm{~N}-\mathrm{NO}_{3}^{-}$and $\delta^{18} \mathrm{O}-\mathrm{NO}_{3}^{-}$values of the $\mathrm{NO}_{3}^{-}$sources used in the SIAR mixing model. For further details, see Material and Methods, SIAR mixing model.

\begin{tabular}{|c|c|c|c|c|c|}
\hline Source & $\begin{array}{l}\delta^{15} \mathrm{~N}^{-\mathrm{NO}_{3}^{-}} \\
(\text {mean } \pm \mathrm{SD})\end{array}$ & $\begin{array}{l}\delta^{18} \mathrm{O}-\mathrm{NO}_{3}^{-} \\
(\text {mean } \pm \mathrm{SD})\end{array}$ & $n$ & Origin & Reference \\
\hline $\begin{array}{l}\mathrm{NO}_{3}^{-} \text {from } \\
\text { atmospheric } \\
\text { deposition }\end{array}$ & $0.3 \pm 1.4$ & $76.7 \pm 6.8$ & 10 & $\begin{array}{l}\text { Warnemünde } \\
\text { (Germany), and } \\
\text { Sännen and Majstre } \\
\text { (Sweden) }\end{array}$ & This study \\
\hline $\begin{array}{l}\mathrm{NO}_{3}^{-} \text {from } \\
\text { pristine soils }\end{array}$ & $1.3 \pm 1.4$ & $1.5 \pm 0.9$ & 5 & Groundwater & Deutsch et al. (2006) \\
\hline $\begin{array}{l}\mathrm{NO}_{3}^{-} \text {from } \\
\text { agricultural runoff }\end{array}$ & $9.9 \pm 1.5$ & $4.6 \pm 1.0$ & 21 & $\begin{array}{l}\text { Tile-drain outlets, } \\
\text { Warnow River }\end{array}$ & Deutsch et al. (2006) \\
\hline $\begin{array}{l}\mathrm{NO}_{3}^{-} \text {from } \\
\mathrm{N}_{2} \text { fixation }\end{array}$ & $-1.0 \pm 1.0$ & $-0.7 \pm 2.9$ & 0 & Estimated & $\begin{array}{l}\text { Carpenter et al. (1999, } \\
\text { 1997); Bourbonnais et } \\
\text { al. (2009, 2012); } \\
\text { Montoya et al. (2002); } \\
\text { Sigman et al. (2009) }\end{array}$ \\
\hline
\end{tabular}

bottle. At the two Swedish stations, rainwater was sampled monthly by the Swedish Environmental Research Institute (IVL) as part of the Swedish national long-term monitoring program. Here, the sampler consisted of a plastic funnel (diameter $20.3 \mathrm{~cm}$ ) connected to an $8-\mathrm{L}$ polyethylene bag. All samples were filtered through pre-combusted Whatman GF/F filters ( $4 \mathrm{~h}$ at $400{ }^{\circ} \mathrm{C}$ ) and stored frozen until further analysis.

\subsection{Nutrient concentrations and dual isotope analysis of $\mathrm{NO}_{3}^{-}$}

Samples were analyzed following a standard protocol for the determination of $\mathrm{NO}_{3}^{-}$and nitrite $\left(\mathrm{NO}_{2}^{-}\right.$) (Grasshoff et al., 1983); the precision of the method is $\pm 0.02 \mu \mathrm{mol} \mathrm{L}-1$. Dual isotope analysis of $\mathrm{NO}_{3}^{-}\left(\delta^{15} \mathrm{~N}-\mathrm{NO}_{3}^{-}\right.$and $\left.\delta^{18} \mathrm{O}-\mathrm{NO}_{3}^{-}\right)$ was carried out using the denitrifier method (Casciotti et al., 2002; Sigman et al., 2001), in which $\mathrm{NO}_{3}^{-}$and $\mathrm{NO}_{2}^{-}$ are quantitatively converted to nitrous oxide $\left(\mathrm{N}_{2} \mathrm{O}\right)$ by $\mathrm{Pseu}$ domonas aureofaciens (ATTC 13985), a bacterial strain that lacks $\mathrm{N}_{2} \mathrm{O}$ reductase activity. In brief, $\mathrm{N}_{2} \mathrm{O}$ is removed from the sample vials by purging with helium and then concentrated and purified in a GasBench II prior to analysis with a Delta Plus mass spectrometer (ThermoFinnigan). $\mathrm{NO}_{2}^{-}$ was not removed since its concentrations were always less than $2 \%$ (referring to the procedure described in Casciotti et al., 2007). $\mathrm{N}$ and $\mathrm{O}$ isotope measurements of roughly $30 \%$ of the samples were replicated in separate batch analyses. Two international standards, IAEA-N3 $\left(\delta^{15} \mathrm{~N}=4.7 \%\right.$ 。 vs. $\mathrm{N}_{2} ; \delta^{18} \mathrm{O} 25.6 \%$ vs. VSMOW $)$ and USGS $34\left(\delta^{15} \mathrm{~N}\right.$ $-1.8 \%$ vs. $\mathrm{N}_{2} ; \delta^{18} \mathrm{O}-27.9 \%$ vs. VSMOW) (Böhlke et al., 2003), were measured with each batch of samples. Samples with $\mathrm{NO}_{3}^{-} / \mathrm{NO}_{2}^{-}$concentrations as low as $1 \mu \mathrm{mol} \mathrm{L}-1$ were analyzed. The sample size for the actual stable isotope measurements was $20 \mathrm{nmol}$ for samples with concentrations $>3.5 \mu \mathrm{mol} \mathrm{L}^{-1}$ and $10 \mathrm{nmol}$ for those with concen- trations $<3.5 \mu \mathrm{mol} \mathrm{L}^{-1}$. Isotope values were corrected after Sigman et al. (2009) for $\delta^{18} \mathrm{O}-\mathrm{NO}_{3}^{-}$; single point correction was referred to IAEA-N3 for $\delta^{15} \mathrm{~N}-\mathrm{NO}_{3}^{-}$. The precision was $<0.2 \%$ or $\delta^{15} \mathrm{~N}$ and $<0.6 \%$ ofor $\delta^{18} \mathrm{O}$. Together with the samples, a culture blank was analyzed to which no sample was added. The isotope ratios are reported using the delta notation in units of per mil (\%o).

\section{$2.3 \quad \mathrm{NO}_{3}^{-}$sources}

To estimate the contribution of different $\mathrm{NO}_{3}^{-}$sources, two isotopes $\delta^{15} \mathrm{~N}-\mathrm{NO}_{3}^{-}$and $\delta^{18} \mathrm{O}-\mathrm{NO}_{3}^{-}(j=2)$ from the four major $\mathrm{NO}_{3}^{-}$sources: (1) atmospheric deposition, (2) runoff from pristine soils, (3) runoff from agricultural land and (4) $\mathrm{N}_{2}$ fixation were applied (Table 2). In this context, $\mathrm{N}_{2}$ fixation was defined as $\mathrm{NO}_{3}^{-}$originating from the degradation and remineralization of nitrogen fixers and therefore carried their low isotopic signal. Thus, for $\mathrm{NO}_{3}^{-}$from $\mathrm{N}_{2}$ fixation, $\delta^{15} \mathrm{~N}$ values of $\sim-2$ to $0 \%$ were assumed, since $\mathrm{N}_{2}$ fixation produces organic material that is only slightly $\mathrm{N}$ depleted against air nitrogen (Carpenter et al., 1999, 1997; Montoya et al., 2002). The $\delta^{18} \mathrm{O}$ values were estimated to be between $-3.8 \%$ and $2.0 \%$, based on measurements in the subtropical northeast Atlantic where $\mathrm{N}_{2}$ fixation was the main source of $\mathrm{N}$ (Bourbonnais et al., 2009) $\left(\delta^{18} \mathrm{O}-\mathrm{NO}_{3}^{-}=2 \%\right.$ ) and the estimated $\delta^{18} \mathrm{O}$ of $\mathrm{NO}_{3}^{-}$deriving from $\mathrm{N}_{2}$ fixation by Sigman et al. (2009) $\left(\delta^{18} \mathrm{O}-\mathrm{NO}_{3}^{-}=-0.2 \%\right.$ ) and Bourbonnais et al. (2012) $\left(\delta^{18} \mathrm{O}-\mathrm{NO}_{3}^{-}=-3.8 \%\right.$ ). 
To expand the data set, we included $\mathrm{NO}_{3}^{-}$isotope data from river water samples, ground water samples, and samples from tile drain outlets collected in 2003 and published in Deutsch et al. (2006). In that study, the Warnow River $(n=2)$ was sampled twice, in January and February 2003. These sources were likewise sampled in winter, since marked seasonal shifts in the isotopic composition of $\mathrm{NO}_{3}^{-}$can occur due to shifts in the origins of the sources (Knapp et al., 2005). Samples from tile drain outlets were used to represent $\mathrm{NO}_{3}^{-}$from agricultural runoff and were obtained from the catchment of the Warnow River, whose waters are strongly influenced by agricultural land use (Pagenkopf, 2001). High $\delta^{15} \mathrm{~N}^{-\mathrm{NO}_{3}^{-}}$values of $9.9 \pm 1.5 \%$ and lower $\delta^{18} \mathrm{O}_{-} \mathrm{NO}_{3}^{-}$values of $4.6 \pm 1.0 \%$ are typical for areas that are influenced by agricultural activities and are similar to studies of Wankel et al. (2006) and Johannsen et al. (2008). Johannsen et al. (2008) found in the rivers Rhine, Elbe, Weser and Ems, with comparable high agricultural activities, $\delta^{15} \mathrm{~N}^{-\mathrm{NO}_{3}^{-}}$values between 8.2 and $11.2 \%$ and $\delta^{18} \mathrm{O}-\mathrm{NO}_{3}^{-}$values from 0.4 to $0.9 \%$ in winter. However, a differentiation between $\mathrm{NO}_{3}^{-}$ from mineral fertilizers and sewage/manure was not done; rather a mixed signal from rivers that are mainly influenced by agricultural activities was taken. Groundwater samples were used as the source of $\mathrm{NO}_{3}^{-}$from pristine land (Deutsch et al., 2006). Their $\delta^{15} \mathrm{~N}_{-} \mathrm{NO}_{3}^{-}$and $\delta^{18} \mathrm{O}-\mathrm{NO}_{3}^{-}$values significantly differed from those of agricultural runoff $(p<0.05)$ but were similar to the values of other areas, such as Biscuit Brook (Burns et al., 2009) and the San River (Koszelnik and Gruca-Rokosz, 2013), where pristine soils were sampled and reflect nitrification activity in soils unaffected by human activity.

The dual isotopes of $\mathrm{NO}_{3}^{-}$values presented in Deutsch et al. (2006) were analyzed according to Silva et al. (2000). In this method, $\mathrm{NO}_{3}^{-}$is chemically converted via anion exchange resins to $\mathrm{AgNO}_{3}^{-}$and the $\delta^{15} \mathrm{~N}_{-} \mathrm{NO}_{3}^{-}$and $\delta^{18} \mathrm{O}$ $\mathrm{NO}_{3}^{-}$values are measured via pyrolysis and isotopic ratio mass spectrometry (for a detailed description, see Deutsch et al., 2006). A normal distribution of the isotopic data from the four sources was confirmed by applying the Shapiro-Wilk normality test. $\delta^{15} \mathrm{~N}^{-\mathrm{NO}_{3}^{-}}$and $\delta^{18} \mathrm{O}-\mathrm{NO}_{3}^{-}$values from $\mathrm{NO}_{3}^{-}$from atmospheric deposition of $0.3 \pm 1.4 \%$ o and $76.7 \pm 6.8 \%$, respectively, are also in line with literature values. The $\delta^{15} \mathrm{~N}$ values of atmospheric $\mathrm{NO}_{3}^{-}$are usually between -15 to $+15 \%$ and the $\delta^{18} \mathrm{O}$ between 63 and $94 \%$ o (Kendall et al., 2007).

Six regions within the catchment of the Baltic Sea were investigated for their potential $\mathrm{NO}_{3}^{-}$sources (Fig. 1). According to the topography of the Baltic Sea, the samples were assigned to four major areas: Western Baltic Sea, Baltic Proper, Gulf of Finland, and Gulf of Bothnia. Additionally, three rivers differing in their degree of anthropogenic impact were included in this study and divided into two groups: northern and southern rivers. Rivers with high nutrient loads drain mainly into the southern Baltic Proper and were represented here by the Nemunas and Warnow Rivers, whose $\mathrm{NO}_{3}^{-}$concentrations in winter can be as high as $260 \mu \mathrm{mol} \mathrm{L}^{-1}$ (Deutsch et al., 2006; Pilkaityte and Razinkovas, 2006). The Gulf of Bothnia receives large amounts of fresh water from rivers represented by the Kalix River. These rivers drain mainly pristine, forested land and have maximum $\mathrm{NO}_{3}^{-}$concentrations of around $20 \mu \mathrm{mol} \mathrm{L}^{-1}$ (Sferratore et al., 2008).

\subsection{SIAR mixing model}

The applied mixing model is described by the following equations:

$$
\begin{aligned}
X_{i j} & =\sum_{k=1}^{K} p_{k}\left(s_{j k}+c_{j k}\right)+\varepsilon_{i j}, \\
s_{j k} & \sim \mathrm{N}\left(\mu_{\mathrm{jk}}, \omega_{\mathrm{jk}}^{2}\right), \\
c_{j k} & \sim \mathrm{N}\left(\lambda_{\mathrm{jk}}, \tau_{\mathrm{jk}}^{2}\right), \\
\varepsilon_{i j} & \sim \mathrm{N}\left(0, \sigma_{\mathrm{j}}^{2}\right),
\end{aligned}
$$

where $X_{i j}$ is the observed isotope value $j$ of the mixture $i$; $i=1,2,3, \ldots, I$ are individual observations; and $j=1,2$, $3, \ldots, J$ are isotopes. $s_{j k}$ is the source value $k$ of isotope $j$ $(k=1,2,3, \ldots, K)$ and is normally distributed, with a mean of $\mu_{j k}$ and a standard deviation of $\omega_{j k} . p_{k}$ is the proportion of source $k$ that needs to be estimated by the model. $c_{j k}$ is the fractionation factor for isotope $j$ on source $k$ and is normally distributed, with a mean of $\lambda_{j k}$ and a standard deviation of $\tau_{j k} . \varepsilon_{i j}$ is the residual error representing additional unquantified variations between mixtures and is normally distributed, with a mean of 0 and a standard deviation of $\sigma_{j}$. Detailed descriptions of the model can be found in Jackson et al. (2009), Moore and Semmens (2008), and Parnell et al. (2010). As noted above, by collecting samples between November and February we minimized the influence of fractionation processes such as assimilation and denitrification that can alter the isotopic signal of $\mathrm{NO}_{3}^{-}$. Therefore in Eq. (1) we assumed that $c_{j k}=0$.

Two different runs of the SIAR model were performed. In the first, for the Western Baltic Sea, Baltic Proper, and Gulf of Finland, all four sources were included in the calculation. In the second, for the Gulf of Bothnia, the southern rivers, and the northern rivers, $\mathrm{N}_{2}$ fixation as a potential $\mathrm{NO}_{3}^{-}$source was excluded since in these areas there is no $\mathrm{N}_{2}$ fixation by diazotrophs because the Gulf of Bothnia is phosphorus limited, in contrast to the Baltic Proper (Graneli et al., 1990).

\section{Results}

\section{1 $\mathrm{NO}_{3}^{-}$concentrations and isotopes}

Winter (November-February) surface $\mathrm{NO}_{3}^{-}$concentrations ranged from a minimum of $2.6 \mu \mathrm{mol} \mathrm{L}^{-1}$ in the open Baltic 
Table 3. Source attribution results: Mean, standard deviation, and minimum and maximum values for the potential contributions of four potential $\mathrm{NO}_{3}^{-}$sources for the areas Western Baltic Sea, Baltic Proper, Gulf of Finland, Gulf of Bothnia, southern rivers, and northern rivers

\begin{tabular}{lcccccccc}
\hline Area & \multicolumn{2}{c}{$\mathrm{NO}_{3}^{-} \begin{array}{c}\text { from atmospheric } \\
\text { deposition }\end{array}$} & \multicolumn{2}{c}{$\mathrm{NO}_{3}^{-}$from pristine soils } & $\mathrm{NO}_{3}^{-}$from agricultural runoff & $\mathrm{NO}_{3}^{-}$from $\mathrm{N}_{2}$ fixation \\
\cline { 2 - 8 } & $\mathrm{Mean} \pm \mathrm{SD}$ & Min-Max & Mean $\pm \mathrm{SD}$ & Min-Max & Mean $\pm \mathrm{SD}$ & Min-Max & Mean $\pm \mathrm{SD}$ & Min-Max \\
\hline Western & $1.1 \pm 0.5$ & $0.0-3.5$ & $7.5 \pm 5.9$ & $0.0-42.0$ & $53.5 \pm 3.2$ & $41.0-66.5$ & $37.9 \pm 5.1$ & $11.0-51.9$ \\
Baltic Sea & & & & & & & & \\
Baltic Proper & $0.1 \pm 0.1$ & $0.0-0.9$ & $2.1 \pm 1.9$ & $0.0-14.7$ & $39.0 \pm 1.6$ & $32.8-45.5$ & $58.8 \pm 2.0$ & $49.3-65.3$ \\
Gulf of Finland & $0.2 \pm 0.2$ & $0.0-2.0$ & $2.4 \pm 2.1$ & $0.0-24.3$ & $51.9 \pm 3.0$ & $40.9-63.4$ & $45.5 \pm 3.2$ & $32.7-59.0$ \\
Gulf of Bothnia & $0.1 \pm 0.1$ & $0.0-0.5$ & $99.0 \pm 0.9$ & $91.7-100.0$ & $1.0 \pm 0.9$ & $0.0-8.2$ & - & - \\
Southern rivers & $0.2 \pm 0.1$ & $0.0-1.3$ & $6.4 \pm 4.2$ & $0.0-24.5$ & $93.5 \pm 4.2$ & $75.2-100.0$ & - & - \\
Northern rivers & $11.8 \pm 1.5$ & $6.6-23.4$ & $75.3 \pm 7.9$ & $33.8-92.8$ & $12.9 \pm 8.1$ & $0.0-57.2$ & - & - \\
\hline
\end{tabular}

Table 4. Comparison of $\delta^{15} \mathrm{~N}^{-\mathrm{NO}_{3}^{-}}$values from surface water samples and $\delta^{15} \mathrm{~N}$ values from sediments samples in sub-regions of the Baltic Sea.

\begin{tabular}{llll}
\hline & $\begin{array}{l}\text { Baltic southern } \\
\text { coastal areas/ } \\
\text { Gulf of Finland }\end{array}$ & $\begin{array}{l}\text { Central Baltic } \\
\text { Proper }\end{array}$ & \\
\hline $\begin{array}{l}\delta^{15} \mathrm{~N} \text { sediments } \\
(\%)\end{array}$ & $7.3 \pm 2.1$ & $3.5 \pm 0.6$ & Voss et al. 2005 \\
$\begin{array}{l}\delta^{15} \mathrm{~N}-\mathrm{NO}_{3}^{-} \text {surface } \\
\text { water column }(\%)\end{array}$ & $7.9 \pm 1.8$ & $3.6 \pm 1.0$ & This study \\
\hline
\end{tabular}

Sea to a maximum of $259 \mu \mathrm{mol} \mathrm{L}^{-1}$ close to the estuaries of the most nutrient-rich rivers, i.e. the Nemunas and Warnow Rivers (Fig. 2, Supplement 1). In most basins of the Baltic Sea, the $\mathrm{NO}_{3}^{-}$concentrations in winter were almost identical, with the exception of the Gulf of Finland, where concentrations were about 2-fold higher $\left(7.6 \pm 0.9 \mu \mathrm{mol} \mathrm{L}^{-1}\right.$; Fig. 2). In the western Baltic Sea, the Baltic Proper, and the Gulf of Bothnia $\mathrm{NO}_{3}^{-}$concentrations were similar with $3.3 \pm 0.6$, $3.4 \pm 0.8$, and $3.7 \pm 0.4 \mu \mathrm{mol} \mathrm{L}^{-1}$, respectively.

Highest nitrate concentrations in the Nemunas River also corresponded to the highest $\delta^{15} \mathrm{~N}^{-\mathrm{NO}_{3}^{-}}$with $10.0 \%$ and vice versa, with lowest concentrations and nitrogen isotope values in the Baltic Proper $\left(1.5 \%\right.$ ). The $\delta^{18} \mathrm{O}-\mathrm{NO}_{3}^{-}$values ranged from $-2.8 \%$ in the Gulf of Bothnia to $10.6 \%$ in the Northern River, Kalix (Fig. 2, Supplement 1).

\subsection{Sources of $\mathrm{NO}_{3}^{-}$}

SIAR calculated that in the southern Baltic Sea, agricultural runoff was the main $\mathrm{NO}_{3}^{-}$source with the highest contribution in the western Baltic Sea with up to $67 \%$ (mean $53.5 \pm 3.2 \%$ ) and in the southern rivers with up to $100 \%$ (mean $93.5 \pm 4.1 \%$ ) (Table 3, Fig. 1). $\mathrm{NO}_{3}^{-}$from atmospheric deposition was negligible with $3.5 \%$ (mean $1.1 \pm 0.5 \%)$ and $\mathrm{NO}_{3}^{-}$from pristine soils lower with up to $42 \%$ (mean $7.5 \pm 5.9 \%$ ) in the western Baltic Sea (Table 3, Fig. 1). In the Baltic Proper, $\mathrm{NO}_{3}^{-}$from $\mathrm{N}_{2}$ fix- ation was the dominant $\mathrm{NO}_{3}^{-}$source with up to $65.3 \%$ (mean $58.8 \pm 2.0 \%$ ) (Table 3, Fig. 1). In the northern Baltic Sea $\mathrm{NO}_{3}^{-}$from atmospheric deposition is only important in the northern rivers with a contribution of up to $23.4 \%$ (mean $11.8 \pm 1.5 \%$ ) (Table 3, Fig. 1). $\mathrm{NO}_{3}^{-}$from pristine soils is mainly transported by the northern rivers $(75.3 \pm 7.9 \%)$ to the Gulf of Bothnia, where SIAR calculated that $99.0 \pm 0.9 \%$ stems from the runoff from pristine soils (Table 3, Fig. 1).

\subsection{Comparison of isotope patterns in the water column and sediments}

The $\delta^{15} \mathrm{~N}$ values from surface water correlated significantly with those from surface sediments, as reported in Voss et al. (2005) $(p<0.001)$ (Fig. 3). Stations for sediment sampling were in close vicinity to stations from water column sampling (Fig. 4). In the Baltic Proper, the $\delta^{15} \mathrm{~N}$ of the surface water $\mathrm{NO}_{3}^{-}$was indistinguishable from the $\delta^{15} \mathrm{~N}$ of the sediment surface $(3.6 \pm 1.0$ and $3.5 \pm 0.6 \%$, respectively; Table 4). In the near-coastal areas of the Baltic Proper and the Gulf of Finland, the $\delta^{15} \mathrm{~N}$ of surface water $\mathrm{NO}_{3}^{-}$was $7.9 \pm 1.8 \%$ o, slightly higher than the surface sediment value for the same area of $7.3 \pm 2.1 \%$ (data in Voss et al., 2005) but still not significant different $(p<0.01)$ (Table 4).

\section{Discussion}

\section{1 $\mathrm{NO}_{3}^{-}$in the Baltic Sea}

The measured winter surface water concentrations of up to $259 \mu \mathrm{mol} \mathrm{L}^{-1}$ are typical for eutrophic systems and similar values have been reported from the Chesapeake Bay and the coastal areas of the North Sea (Dähnke et al., 2010; Francis et al., 2013). The concentrations of nutrients in the sub-basins of the Baltic Sea reflect the densities of the human populations in the vicinity of the adjacent sub-catchments. Thus, in the near-coastal area of the southern Baltic Proper, $\mathrm{NO}_{3}^{-}$concentrations were higher than in the northern parts, since the 

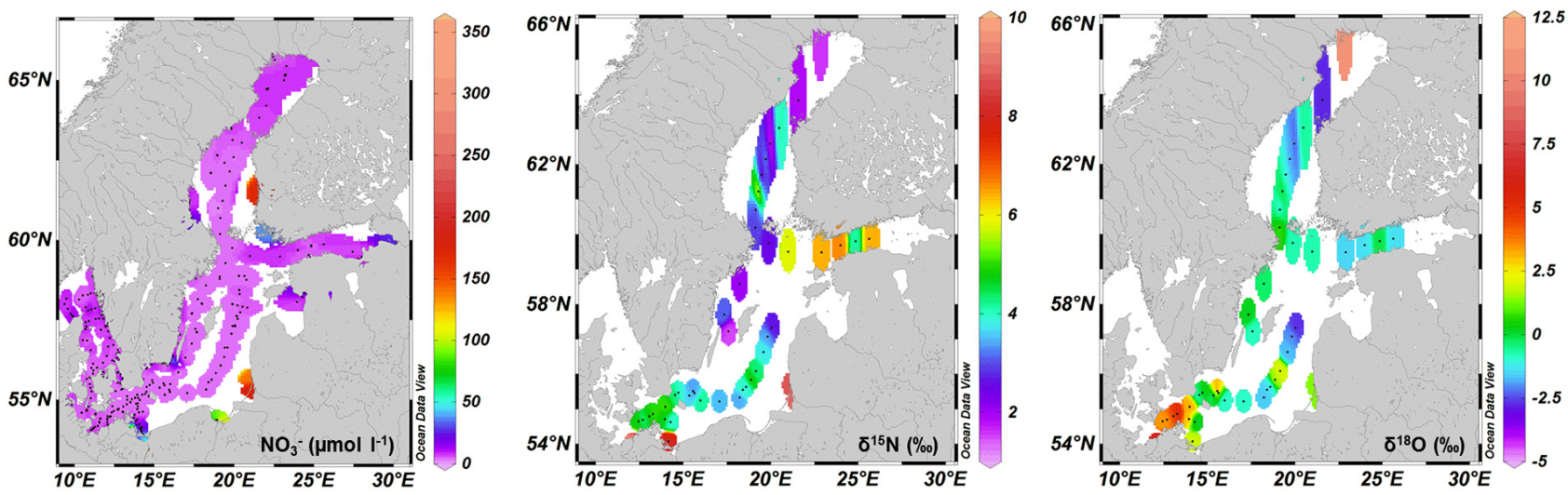

Figure 2. Surface water column $\mathrm{NO}_{3}^{-}$concentrations (a), $\delta^{15} \mathrm{~N}-\mathrm{NO}_{3}^{-}$values (b), and $\delta^{18} \mathrm{O}-\mathrm{NO}_{3}^{-}$values (c) for the Baltic Sea. Stations are indicated as black dots. Additional $\mathrm{NO}_{3}^{-}$concentrations were obtained from the Data Assimilation System (DAS) (http://nest.su.se/das/) in winter (November-February) of the years 2000 to 2012.

catchment areas of Germany, Poland, and the Baltic States are much more densely populated ( $>500$ inhabitants $\mathrm{km}^{-2}$ ) and the land is intensively used for agricultural purposes. The northern regions are dominated by boreal forests and less populated $\left(<10\right.$ inhabitants $\mathrm{km}^{-2}$ ) (Lääne et al., 2005; Stepanauskas et al., 2002; Voss et al., 2011). Consequently, for the southern Baltic Proper a relationship between fluvial $\mathrm{NO}_{3}^{-}$loads and $\mathrm{NO}_{3}^{-}$concentrations in coastal waters could be established that indicates a direct impact of riverine nutrients on coastal waters (Voss et al., 2011; HELCOM, 2009). However, there was no similar correlation between riverine $\mathrm{N}$ loads and nutrient concentrations either for the coastal areas of the Gulf of Bothnia or for the open waters of the Baltic Proper (Voss et al. 2011). The Gulf of Bothnia is the only sub-basin in which the effects of eutrophication are so far minor, although Lundberg et al. (2009) and Conley et al. (2011) reported a degradation in the water quality from north to south and from the outer to the inner coastal area of the Gulf, with seasonal hypoxia at many sites. Trends of increasing nutrient levels should be interpreted as a warning signal for the future and highlight the need for management approaches based on sound knowledge of the many potential sources of $\mathrm{NO}_{3}^{-}$.

In the Gulf of Finland, which is regarded as the most heavily eutrophic sub-basin of the Baltic Sea, a consequence of high receiving nutrient loads from the Neva River and the city of St. Petersburg (Lundberg et al., 2005), $\mathrm{NO}_{3}^{-}$concentrations were about 2 -fold higher $\left(7.6 \pm 0.9 \mu \mathrm{mol} \mathrm{L}^{-1}\right)$ compared to the rest of the Baltic Sea sub-basins, where concentrations in winter were almost identical. This shows that $\mathrm{NO}_{3}^{-}$concentrations alone cannot be used to identify $\mathrm{NO}_{3}^{-}$ sources for the sub-basins; rather, stable $\mathrm{NO}_{3}^{-}$isotopes values allow for accurate source determination, as we will show in the following sections.

\subsection{Sources of $\mathrm{NO}_{3}^{-}$}

The use of $\mathrm{NO}_{3}^{-}$stable isotopes for source identification is complicated when the mixing of multiple $\mathrm{N}$ sources with overlapping isotopic ranges occurs together with microbial processes such as nitrification, assimilation, and denitrification (Kendall, 1998; Wankel et al., 2006). In this study, we assumed that the effects of fractionation by microbial processes were negligible because all our samples were collected in winter, at a mean temperature of $3.1 \pm 1.3^{\circ} \mathrm{C}$ (data not shown), when microbial activity is low (Pfenning and McMahon, 1997), as confirmed in a study of nitrification in the Baltic Sea by Jäntti et al. (2011). They showed that in the Gulf of Finland although nitrification potentials may be high during cold months, in situ nitrification is undetectable, whereas the rate increases progressively towards the summer.

We are aware that the variability of the source signals must be taken into account in source attributions. Both Xue et al. (2012, 2013) and Yang et al. (2013) showed that SIAR can be applied in $\mathrm{NO}_{3}^{-}$source identification, although the resolution of this model is largely determined by the uncertainty of the isotopic composition of the sources. In the studies of both groups, the means and variances of the sources were calculated mostly from literature values, which were not obtained in the investigation areas, nevertheless they received consistent results. In contrast, in our study, the isotopic composition of the sources, except $\mathrm{NO}_{3}^{-}$from $\mathrm{N}_{2}$ fixation, was determined from samples obtained within the study area. In our calculations we considered the impact of the variability of the sources and report not only mean values and error estimates, but also minimum and maximum contributions, as suggested by Fry (2013) (Table 3).

\section{3 $\mathrm{NO}_{3}^{-}$from agricultural runoff}

The isotopic values of riverine $\mathrm{NO}_{3}^{-}$were previously shown to be enriched when agricultural land is the source of inputs 


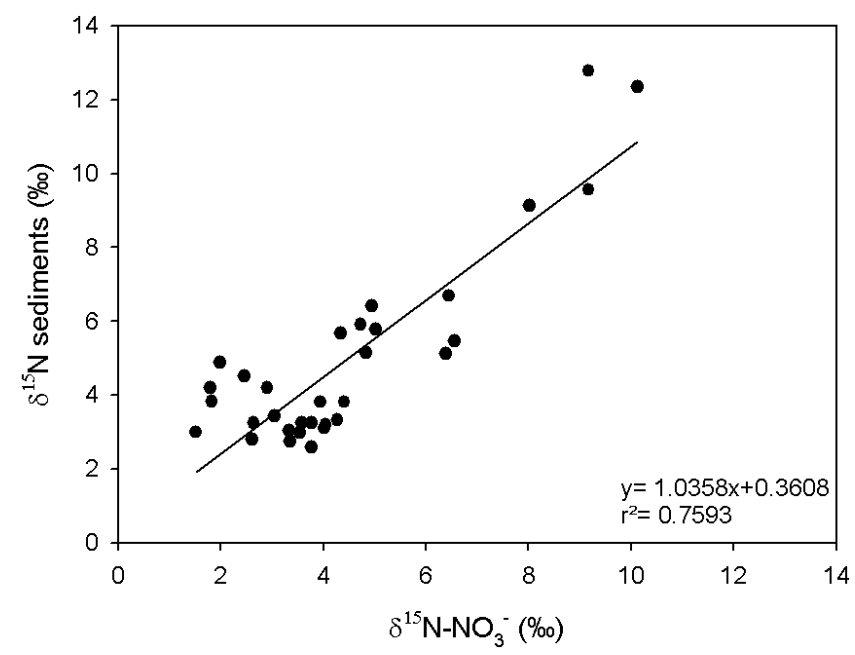

Figure 3. $\delta^{15} \mathrm{~N}$ from sediment samples vs. $\delta^{15} \mathrm{~N}-\mathrm{NO}_{3}^{-}$from surface water samples. $\delta^{15} \mathrm{~N}$ values from sediments were taken from Voss et al. (2005). The positive slope suggests a tight coupling between $\delta^{15} \mathrm{~N}-\mathrm{NO}_{3}^{-}$in surface waters and $\delta^{15} \mathrm{~N}$ in sediment samples.

(Johannsen et al., 2008; Mayer et al., 2002; Voss et al., 2006). Catchments with high percentages of agricultural and/or urban land use export $\mathrm{NO}_{3}^{-}$with $\delta^{15} \mathrm{~N}^{-\mathrm{NO}_{3}^{-}}$values of around $7 \%$. In the same study, the oxygen isotope ratios of $\mathrm{NO}_{3}^{-}$were almost uniformly $13 \pm 1 \%$ (Mayer et al., 2002). Johannsen et al. (2008) measured $\delta^{15} \mathrm{~N}^{-N^{-}}{ }_{3}^{-}$values of $11.3 \%$ in highly eutrophic rivers draining into the North Sea, whereas the highest $\delta^{18} \mathrm{O}-\mathrm{NO}_{3}^{-}$value was $2.2 \%$. In the Oder River outflow, a main $\mathrm{NO}_{3}^{-}$contributor to the Baltic Sea, $\delta^{15} \mathrm{~N}_{-} \mathrm{NO}_{3}^{-}$of $7.6 \%$ and $\delta^{18} \mathrm{O}-\mathrm{NO}_{3}^{-}$of $2.9 \%$ o were determined (Korth et al., 2013). Our measurements for the Warnow and Nemunas Rivers fall in the expected range, with a mean $\delta^{15} \mathrm{~N}^{-\mathrm{NO}_{3}^{-}}$of $9.2 \%$ and a mean $\delta^{18} \mathrm{O}-\mathrm{NO}_{3}^{-}$ of $3.1 \%$, and are consistent with the high percentages of agricultural land in the river catchment areas: $50 \%$ for the Warnow River (Pagenkopf, 2001) and 50\% for the Nemunas River (C. Humborg, personal communication, 2011). For both, SIAR calculations indicated that $75.2-100 \%$ (mean $93.5 \pm 4.2 \%$ ) of the $\mathrm{NO}_{3}^{-}$pool is from agricultural runoff. $\mathrm{NO}_{3}^{-}$with this signature seems to be transported to the central Baltic Sea, since SIAR-based estimates showed significant percentages of agriculturally derived $\mathrm{NO}_{3}^{-}$in the Western Baltic Sea (41.0-66.5\%; mean: 53.5 $\pm 3.2 \%$ ), the Baltic Proper (32.8-45.5\%; mean: $39.0 \pm 1.6 \%$ ), and the Gulf of Finland (40.9-63.4\%; mean: 51.9 $\pm 3.0 \%$ ). However, high percentages were only expected for the Gulf of Finland and the Western Baltic Sea, where large N loads from agricultural land have been documented (Hong et al., 2012). Indeed, for the Baltic Proper, the sizeable contribution of agricultural $\mathrm{NO}_{3}^{-}(39.0 \pm 1.6 \%)$ was surprising and contrasted with previous findings that nearly excluded riverine $\mathrm{NO}_{3}^{-}$as a major nutrient source for the central Baltic Sea (Voss et al.,

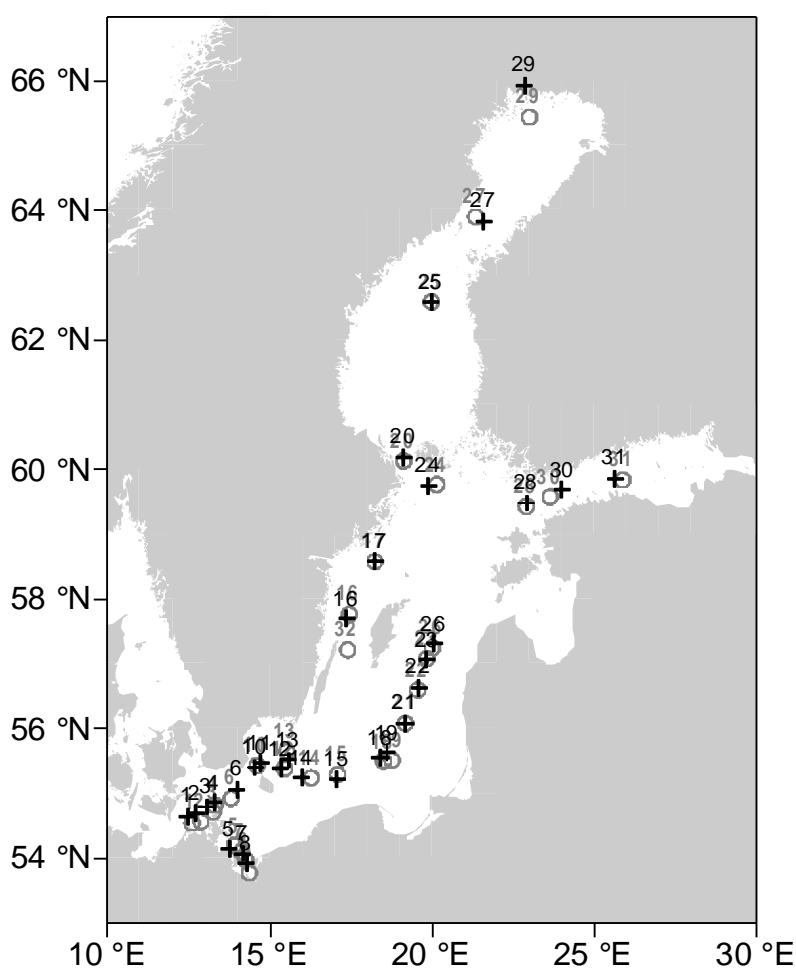

Figure 4. Station map for the comparison of isotope patterns in the water column and sediments. Gray circles are the stations referred to in Voss et al. (2005) and black crosses are those from this study. Isotope values were compared at stations with the same number.

2005, 2011). However, Neuman (2000) estimated that $13 \%$ of the $\mathrm{N}$ input of the Oder River is transported to the central Baltic Sea, while Radtke et al. (2012) could show, using a source attribution technique in the three-dimensional ecosystem model ERGOM (Ecological ReGional Ocean Model), that at least a part of the dissolved inorganic nitrogen (DIN) load from the Vistula River, the main $\mathrm{NO}_{3}^{-}$contributor to the Baltic Sea (Wulff et al., 2009), enters the Baltic Proper. This 3-D model comprises a circulation model, a thermodynamic ice model, and a biogeochemical model and utilizes the Modular Ocean Model, MOM3.1 (Radtke et al., 2012).

Another explanation for the high estimated agricultural influence in our study could be the intrusion of water containing $\mathrm{NO}_{3}^{-}$with similar $\mathrm{NO}_{3}^{-}$isotope values as our agricultural $\mathrm{NO}_{3}^{-}$source during mixing/advection from below the halocline. Deep-water $\mathrm{NO}_{3}^{-}$in the Baltic Sea has a $\delta^{15} \mathrm{~N}$ of about $7 \%$ (Frey et al., unpublished data), which is higher than the average deep-water ocean $\mathrm{NO}_{3}^{-}$signature of $5 \%$ o (Sigman et al., 2000). This elevated $\delta^{15} \mathrm{~N}_{\text {in }} \mathrm{NO}_{3}^{-}$mainly comes from water column denitrification in the oxic-anoxic interface in water at a depth of about $100 \mathrm{~m}$ (Dalsgaard et al., 2013). However, the year-to-year variations in DIN due to vertical mixing and advection from below the halocline are sensitive to hydrographic conditions. When the halocline is weak and well ventilated, oxygen conditions improve, resulting in 
higher DIN concentrations in deep waters and greater advection and/or mixing (Vahtera et al., 2007) such that the $\mathrm{NO}_{3}^{-}$ contribution from below the halocline is difficult to estimate.

Overall, the range of $32.8-45.5 \%$ (mean: $39.0 \pm 1.6 \%$ ) determined for $\mathrm{NO}_{3}^{-}$presumably originating from agricultural runoff has to be considered with caution, because the former imprint of deep water column denitrification and mixing/advection of this isotopically enriched $\mathrm{NO}_{3}^{-}$from below the halocline with the residual winter surface $\mathrm{NO}_{3}^{-}$pool could have resulted in an overestimation of the percentage of $\mathrm{NO}_{3}^{-}$from agricultural runoff in the Baltic Proper.

\section{4 $\mathrm{NO}_{3}^{-}$from $\mathrm{N}_{2}$ fixation}

The average $\delta^{15} \mathrm{~N}^{-\mathrm{NO}_{3}^{-}}$value of $3.6 \%$ of the Baltic Proper is slightly lower than the ocean average of around $5 \%$ (Sigman et al., 2000) and presumably reflects the influence of $\mathrm{N}_{2}$ fixation. This is because the $\delta^{15} \mathrm{~N}$ of newly fixed $\mathrm{N}$ is between -2 and $0 \%$ such that $\mathrm{NO}_{3}^{-}$has slightly lower $\delta^{15} \mathrm{~N}$ values (Knapp et al., 2005; Liu et al., 1996). The $\delta^{18} \mathrm{O}-\mathrm{NO}_{3}^{-}$ value of $-0.5 \%$ in the Baltic Proper is also slightly lower than the ocean average of $1.5 \%$, and close to our theoretical considered value of $-0.7 \pm 2.9 \%$ after the degradation and remineralization of $\mathrm{N}_{2}$ fixers.

$\mathrm{N}_{2}$ fixers are abundant in summer, reflecting the stimulation of their growth by the low $\mathrm{N} / \mathrm{P}$ ratios. $\mathrm{N}$ in the cyanobacterial biomass is remineralized over the winter months and the resulting $\mathrm{NO}_{3}^{-}$remains in the water masses down to the halocline. Our results show that the contribution of $\mathrm{N}_{2}$ fixation by diazotrophs to the $\mathrm{NO}_{3}^{-}$pool is $49.3-65.3 \%$ (mean $58.8 \pm 2.0 \%$ ). This is slightly higher compared to the data reported by Wasmund et al. (2001), who estimated that $39 \%\left(370 \mathrm{kt} \mathrm{yr}^{-1}\right.$ ) of a total input of $955 \mathrm{kt} \mathrm{N} \mathrm{yr}^{-1}$ (HELCOM, 2002) stems from $\mathrm{N}_{2}$ fixations in the central Baltic Sea. Both Radtke et al. (2012) and Voss et al. (2005) concluded that $\mathrm{N}_{2}$ fixation was the main $\mathrm{NO}_{3}^{-}$source in the Baltic Proper. Using an independent approach, we were able to confirm the contribution of $\mathrm{N}_{2}$ fixation in this area. In addition, we found that $\mathrm{N}_{2}$ fixation is also a major source of $\mathrm{NO}_{3}^{-}$in the Western Baltic Sea and the Gulf of Finland (respectively, $11.0-51.9 \%$ (mean $37.9 \pm 5.1 \%$ ) and $32.7-$ $59.0 \%$ (mean $45.5 \pm 3.2 \%$ )). This finding is consistent with our current understanding of $\mathrm{N}_{2}$ fixation in the Gulf of Finland (Vahtera et al., 2005), whereas the western Baltic Sea is rather perceived as an area with no $\mathrm{N}_{2}$ Fixation activity (Stal et al., 2003). In summary, our results provide important evidence that $\mathrm{N}_{2}$ fixation by cyanobacteria is a significant $\mathrm{N}$ source not only in the Baltic Proper but also in the Western Baltic Sea and Gulf of Finland.

\section{$4.5 \mathrm{NO}_{3}^{-}$from atmospheric deposition}

$\mathrm{NO}_{3}^{-}$from atmospheric deposition is generally heavily enriched in ${ }^{18} \mathrm{O}(>60 \%$ o because of reactions involving ozone $\left(\mathrm{O}_{3}\right)$, which is anomalously enriched in heavy oxygen iso- topes (Durka et al., 1994; Kendall et al., 2007). This is consistent with the $\delta^{18} \mathrm{O}$ measurements at the three stations around the Baltic Sea, where the averaged isotope value in winter was $77 \%$ o (Table 1).

Our results show that direct inputs of atmospheric deposition contribute less $\mathrm{NO}_{3}^{-}$than all other sources. Indeed, among all basins of the Baltic Sea, that has a total area of $415.266 \mathrm{~km}^{2}$, the maximum mean contribution was in the Western Baltic Sea 0 to $3.5 \%$ (mean $1.1 \pm 0.5 \%$ ). Moreover, using a data set from Michaels et al. (1993), Duce et al. (2008) estimated that even an extremely rare and large atmospheric deposition event distributed over a $25 \mathrm{~m}$ mixedlayer depth would increase the reactive $\mathrm{N}$ concentration only by around $0.045 \mu \mathrm{mol} \mathrm{L}^{-1}$. A study in the Kattegat estimated an input of $52 \mathrm{kt} \mathrm{N} \mathrm{yr}^{-1}$ from atmospheric deposition, which implied rather limited nutritional support for phytoplankton (Spokes et al., 2006). Taking into account that in the Baltic Proper, with an area of $211.069 \mathrm{~km}^{2}$, in winter the mixedlayer depth is $80-100 \mathrm{~m}$ and that the residual $\mathrm{NO}_{3}^{-}$pool, with a concentration of $3.6 \mu \mathrm{mol} \mathrm{L}{ }^{-1}$, has a $\delta^{18} \mathrm{O}^{-\mathrm{NO}_{3}^{-}}$of $-0.5 \%$, a similar rain event with a $\delta^{18} \mathrm{O}$ of $76.7 \%$ o (Table 1) would increase the $\delta^{18} \mathrm{O}-\mathrm{NO}_{3}^{-}$of the residual $\mathrm{NO}_{3}^{-}$ pool only by $0.2-0.3 \%$, which is within our analytical error. Even though several rain events typically occur during winter, their influence seems to be too low to leave a detectable isotopic imprint. Additionally, the $\mathrm{NO}_{3}^{-}$from atmospheric deposition is presumably intensively cycled through the organic $\mathrm{N}$ pool in spring and summer such that after several mineralization cycles its origin is difficult to recognize isotopically (Mayer et al., 2002).

In the Kalix River $\delta^{18} \mathrm{O}-\mathrm{NO}_{3}^{-}$was clearly enriched $(10.6 \%$ ) compared to the values determined for the Baltic Sea. We calculated that in this river up to $23.4 \%$ (mean $11.8 \pm 1.5 \%$ ) of the $\mathrm{NO}_{3}^{-}$originates from atmospheric deposition. Mayer et al. (2002) compared the isotopic $\mathrm{NO}_{3}^{-}$signature of 16 watersheds in the USA and were able to show that riverine $\mathrm{NO}_{3}^{-}$derived from atmospheric $\mathrm{NO}_{3}^{-}$deposition and not from nitrification in soils is the dominant $\mathrm{N}$ input in predominantly forested watersheds, when riverine $\mathrm{NO}_{3}^{-}$concentrations are generally low. Therefore only in the Kalix River, where up to $97 \%$ of the catchment with a size of $18.130 \mathrm{~km}^{2}$ is covered by forests and $\mathrm{NO}_{3}^{-}$concentrations are low during winter (Voss et al., 2011), was the imprint of $\mathrm{NO}_{3}^{-}$from atmospheric deposition visible; by contrast, in the southern Baltic Sea and the rivers draining into it, the anthropogenic influence due to agriculture is very high and therefore masks atmospheric contributions. However, $\mathrm{NO}_{3}^{-}$loads to the northern Baltic Sea from the Kalix River and other, similar boreal rivers are small, comprising only about $20 \%$ of the sea's total $\mathrm{N}$ load (Voss et al., 2011). Thus, overall, we assume that atmospheric deposition is a very minor source of $\mathrm{NO}_{3}^{-}$in the Baltic Sea. 


\section{6 $\mathrm{NO}_{3}^{-}$from pristine soils}

In general, in rivers such as the Kalix River, whose catchments include pristine vegetation, $\delta^{15} \mathrm{~N}^{-\mathrm{NO}_{3}^{-}}$values are low while those of $\delta^{18} \mathrm{O}-\mathrm{NO}_{3}^{-}$are high (Voss et al., 2006). This finding was confirmed in the present study, in which $\delta^{15} \mathrm{~N}$ $\mathrm{NO}_{3}^{-}$and $\delta^{18} \mathrm{O}-\mathrm{NO}_{3}^{-}$values of $1.6 \%$ and $10.6 \%$, respectively, were determined. In the Kalix River, the $\mathrm{NO}_{3}^{-}$contribution from the runoff of pristine soils as determined by SIAR is $33.8-92.8 \%$ (mean $75.3 \pm 7.9 \%$ ). In pristine soils the isotopic $\mathrm{NO}_{3}^{-}$signal is mainly derived from nitrification, which is in agreement with previous studies of small catchments, where much of the $\mathrm{NO}_{3}^{-}$was shown to be of microbial origin (Campbell et al., 2002; Kendall et al., 2007; Mayer et al., 2002). Similar $\delta^{15} \mathrm{~N}^{-\mathrm{NO}_{3}^{-}}$values were reported for areas where pristine soils were also sampled. For example, $\delta^{15} \mathrm{~N}$ $\mathrm{NO}_{3}^{-}$and $\delta^{18} \mathrm{O}-\mathrm{NO}_{3}^{-}$values of 1.9 and $2.8 \%$ were determined for Biscuit Bay (Burns et al., 2009) and 2.9 and 2.8\%o for the San River (Koszelnik and Gruca-Rokosz, 2013), respectively. The higher $\delta^{18} \mathrm{O}-\mathrm{NO}_{3}^{-}$values of the Kalix River can, as discussed above, be attributed to atmospheric deposition.

For the Gulf of Bothnia, where the catchment is dominated by pristine areas like forests $(50 \%)$ and shrubs $(20 \%), \mathrm{NO}_{3}^{-}$ from pristine soils contributes $91.7-100 \%(99.0 \pm 0.9 \%)$. However, for the Baltic Proper the $\mathrm{NO}_{3}^{-}$contribution from pristine soils is negligible, because the $\mathrm{NO}_{3}^{-}$derived from nitrification is very low in concentrations and remains in the Gulf because of the cyclonic circulation in the Bothnian Sea and Bothnian Bay (Humborg et al., 2003) and the high residence time of the water $(7.4 \mathrm{yr})$ which results in a rather slow exchange with the rest of the Baltic Sea (Myrberg and Andrejev, 2006).

\subsection{Comparison of isotope patterns in the water column and sediments}

Correlations between $\delta^{15} \mathrm{~N}$ values from the water column and surface sediment is a common feature in coastal basins, like Cariaco Basin (Thunell et al., 2004), Guaymas Basin, Monterey Bay, and San Pedro Basin (Altabet et al., 1999). This occurs when $\mathrm{NO}_{3}^{-}$in the surface mixed layer is fully consumed, which is the case in the Baltic Proper during the spring bloom, when the only significant loss comes from the sinking of particulate nitrogen (Altabet et al., 1999). Moreover, high organic matter preservation seems to stimulate the similarity in the $\delta^{15} \mathrm{~N}$ in the surface water and sediments as seen in other depositional environments (Thunell et al., 2004).

Overall, the comparison with the sediment data set from Voss et al. (2005) shows that the isotopic signature of $\mathrm{NO}_{3}^{-}$ in the euphotic layer of the Baltic Sea is directly transferred to the particulate organic nitrogen pool and is subsequently found in the sediment surface as detritus, thus conserving information about the origin of this $\mathrm{NO}_{3}^{-}$source. Addition- ally, we could show how consistent the nitrogen input to the sediments is over the years. Even though, our surface water samples were sampled from 2008 to 2011, the surface sediment samples from 1993 to 2003 and deposited in the period of approximately $10 \mathrm{yr}$ before collection, the comparison of the $\delta^{15} \mathrm{~N}$ values showed that there is no significant difference. Coastal areas preserve the isotope signature of riverine sources while the open Baltic Sea sediments indeed mirror the nitrogen input dominated by $\mathrm{N}_{2}$ fixation. Moreover the data demonstrate that no change over time in the input of $\mathrm{NO}_{3}^{-}$sources has occurred.

\section{Conclusions}

By combining dual isotope data of winter $\mathrm{NO}_{3}^{-}\left(\delta^{15} \mathrm{~N}^{-\mathrm{NO}_{3}^{-}}\right.$ and $\delta^{18} \mathrm{O}_{-} \mathrm{NO}_{3}^{-}$) in surface waters with a Bayesian isotope mixing model (SIAR), we estimated the contribution of four major $\mathrm{NO}_{3}^{-}$sources for the different basins of the Baltic Sea. A clear shift in the source of $\mathrm{NO}_{3}^{-}$inputs, from agricultural sources in the south to runoff from pristine soils in the north, was identified. However, we could not fully determine how much of the agriculturally derived $\mathrm{NO}_{3}^{-}$entering the Baltic Sea finally ends up in the open waters of its central region, where the addition of deep-water $\mathrm{NO}_{3}^{-}$with similar isotope values might falsely, indicate a higher contribution. However, we were able to show that $\mathrm{N}_{2}$ fixation is an important $\mathrm{NO}_{3}^{-}$source in the central Baltic Sea while the contribution of $\mathrm{NO}_{3}^{-}$from atmospheric deposition is only a minor one.

Because they are particularly sensitive to human pressure and global climate change, marginal seas, including the Baltic Sea, will no doubt be affected by the increases in temperature and precipitation predicted for the near future (BACC, 2008). Indeed, increasing atmospheric depositions of $\mathrm{NO}_{3}^{-}$in the world's oceans have already been reported, by Duce et al. (2008) and Kim et al. (2011) and, may impact northern catchments of the Baltic Sea to a larger extent. Additionally, in coastal waters under increasing eutrophication pressure the efficiency of $\mathrm{NO}_{3}^{-}$removal was shown to be reduced (Lunau et al., 2013; Mulholland et al., 2008), and this additional $\mathrm{NO}_{3}^{-}$may alter the biogeochemical cycle. Therefore, the identification of $\mathrm{NO}_{3}^{-}$sources, especially as anticipated in response to global climate change, is important for future environmental management strategies for the Baltic Sea and other marine environments. We suggest that with an adaption of the potential sources the approach used in this study can easily be applied in other environments where $\mathrm{NO}_{3}^{-}$is a major $\mathrm{N}$ contributor.

The Supplement related to this article is available online at doi:10.5194/bg-11-4913-2014-supplement. 
Acknowledgements. The authors thank Matthias Labrenz, Sven Trinkler, Frederik Nordblad, Evelina Griniene and the Swedish Environmental Research Institute, in particular A. Svensson, for taking the samples, and gratefully acknowledge laboratory assistance from Iris Liskow. The authors acknowledge funding from the German Science Foundation (DFG; VO 487/11-1) and the "Come back to research" scholarship of the Leibniz Institute for Baltic Sea Research Warnemünde.

Edited by: T. Treude

\section{References}

Altabet, M. A., Pilskaln, C., Thunell, R., Pride, C., Sigman, D., Chavez, F., and Francois, R.: The nitrogen isotope biogeochemistry of sinking particles from the margin of the Eastern North Pacific, Deep Sea Res. Pt. I Oceanogr. Res. Pap., 46, 655-679, 1999.

BACC: Assessment of climate change for the Baltic Sea Basin, edited by: Bolle, H.-J., Menenti, M., and Rasool, I., Springer, Berlin Heidelberg, 2008.

Böhlke, J. K., Mroczkowski, S. J., and Coplen, T. B.: Oxygen isotopes in nitrate: new reference materials for ${ }^{18} \mathrm{O}:{ }^{17} \mathrm{O}:{ }^{16} \mathrm{O}$ measurements and observations on nitrate-water equilibration, Rapid Commun. Mass Spectrom., 17, 1835-1846, 2003.

Bourbonnais, A., Lehmann, M. F., Waniek, J. J., and Schulz-Bull, D. E.: Nitrate isotope anomalies reflect N2 fixation in the Azores Front region (subtropical NE Atlantic), J. Geophys. Res., 114, C03003, doi:10.1029/2007JC004617, 2009.

Bourbonnais, A., Lehmann, M. F., Butterfield, D. A., and Juniper, S. K.: Subseafloor nitrogen transformations in diffuse hydrothermal vent fluids of the Juan de Fuca Ridge evidenced by the isotopic composition of nitrate and ammonium, Geochem. Geophys. Geosyst., 13, Q02T01, doi:10.1029/2011GC003863, 2012.

Burns, D., Boyer, E., Elliott, E., and Kendall, C.: Sources and transformations of nitrate from streams draining varying land uses: evidence from dual isotope analysis, J. Environ. Qual., 38, 11491159, 2009.

Campbell, D., Kendall, C., Chang, C. C. Y., Silva, S. R., and Tonnessen, K. A.: Pathways for nitrate release from an alpine watershed: Determination using $\delta 15 \mathrm{~N}$ and $\delta 18 \mathrm{O}$, Water Resour. Res., 38, 1-9, 2002.

Carpenter, E. J., Harvey, H. R., Fry, B., and Capone, G. G.: Biogeochemical tracers of the marine cyanobacterium Trichodesmium, Deep. Res. I, 44, 27-38, 1997.

Carpenter, E., Montoya, J., Burns, J., Mulholland, M. R., Subramaniam, A., and Capone, D. G.: Extensive bloom of a $\mathrm{N}_{2}$-fixing diatom/cyanobacterial association in the tropical Atlantic Ocean, Mar. Ecol. Prog. Ser., 185, 273-283, 1999.

Casciotti, K. L., Sigman, D. M., Hastings, M. G., Böhlke, J. K., and Hilkert, A.: Measurement of the Oxygen Isotopic Composition of Nitrate in Seawater and Freshwater Using the Denitrifier Method, Anal. Chem., 74, 4905-4912, 2002.

Casciotti, K. L., Böhlke, J. K., McIlvin, M. R., Mroczkowski, S. J., and Hannon, J. E.: Oxygen isotopes in nitrite: analysis, calibration, and equilibration, Anal. Chem., 79, 2427-36, 2007.

Conley, D. J., Carstensen, J., Vaquer-Sunyer, R., and Duarte, C. M.: Ecosystem thresholds with hypoxia, Hydrobiologia, 629, 21-29, 2009.
Conley, D. J., Carstensen, J., Aigars, J., Axe, P., Bonsdorff, E., Eremina, T., Haahti, B.-M., Humborg, C., Jonsson, P., Kotta, J., Lännegren, C., Larsson, U., Maximov, A., Medina, M. R., Lysiak-Pastuszak, E., Remeikaité-Nikiené, N., Walve, J., Wilhelms, S., and Zillén, L.: Hypoxia is increasing in the coastal zone of the Baltic Sea., Environ. Sci. Technol., 45, 6777-83, 2011.

Dalsgaard, T., De Brabandere, L., and Hall, P. O. J.: Denitrification in the water column of the central Baltic Sea, Geochim. Cosmochim. Acta, 106, 247-260, 2013.

Dähnke, K., Emeis, K., Johannsen, A., and Nagel, B.: Stable isotope composition and turnover of nitrate in the German Bight, Mar. Ecol. Prog. Ser., 408, 7-18, 2010.

Deutsch, B., Mewes, M., Liskow, I., and Voss, M.: Quantification of diffuse nitrate inputs into a small river system using stable isotopes of oxygen and nitrogen in nitrate, Org. Geochem., 37, 1333-1342, 2006.

Duce, R. A., LaRoche, J., Altieri, K., Arrigo, K. R., Baker, A. R., Capone, D. G., Cornell, S., Dentener, F., Galloway, J., Ganeshram, R. S., Geider, R. J., Jickells, T., Kuypers, M. M., Langlois, R., Liss, P. S., Liu, S. M., Middelburg, J. J., Moore, C. M., Nickovic, S., Oschlies, A., Pedersen, T., Prospero, J., Schlitzer, R., Seitzinger, S., Sorensen, L. L., Uematsu, M., Ulloa, O., Voss, M., Ward, B., and Zamora, L.: Impacts of Atmospheric Anthropogenic Nitrogen on the Open Ocean, Science, 320, 893 897, 2008.

Durka, W., Schulze, E., Gebauer, G., and Voerkeliust, S.: Effects of forest decline on uptake and leaching of deposited nitrate determined from $15 \mathrm{~N}$ and $18 \mathrm{O}$ measurements, Nature, 372, 765-767, 1994.

Elmgren, R.: Understanding Human Impact on the Baltic Ecosystem: Changing Views in Recent Decades, Ambio, 30, 222-231, 2001.

Finni, T., Kononen, K., Olsonen, R., and Wallström, K.: The histroy of cyanobacterial blooms, Ambio, 30, 172-178, 2001.

Francis, C. a, O’Mullan, G. D., Cornwell, J. C., and Ward, B. B.: Transitions in nirS-type denitrifier diversity, community composition, and biogeochemical activity along the Chesapeake Bay estuary, Front. Microbiol., 4, 237 pp., 2013.

Fry, B.: Alternative approaches for solving underdetermined isotope mixing problems, Mar. Ecol. Prog. Ser., 472, 1-13, 2013.

Galloway, J. N., Aber, J. D., Erisman, J. W., Seitzinger, S. P., Howarth, R. W., Cowling, E. B., and Cosby, B. J.: The Nitrogen Cascade, Bioscience, 53, 341-356, 2003.

Graneli, E., Wallstrom, K., Larsson, U., Graneli, W., and Elmgren, R.: Nutrient Limitation of Primary Production in the Baltic Sea Area, Ambio, 19, 142-151, 1990.

Grasshoff, K., Ehrhardt, M., and Kremling, K.: Methods of Seawater Analysis, Verlag Chemie, 1983.

Gruber, N. and Galloway, J. N.: An Earth-system perspective of the global nitrogen cycle, Nature, 451, 293-296, 2008.

HELCOM: Fourth periodic assessment of the state of the marine environment of the Baltic Sea area 1994-1998, Balt. Sea Environ. Proc. No. B, 82, 215 pp., 2002.

HELCOM: Eutrophication in the Baltic Sea - An integrated thematic assessment of the effects of nutrient enrichment and eutrophication in the Baltic Sea region, Balt. Sea Environ. Proc. No. B, 115, 148 pp., 2009. 
Hong, B., Swaney, D. P., Mörth, C.-M., Smedberg, E., Eriksson Hägg, H., Humborg, C., Howarth, R. W., and Bouraoui, F.: Evaluating regional variation of net anthropogenic nitrogen and phosphorus inputs (NANI/NAPI), major drivers, nutrient retention pattern and management implications in the multinational areas of Baltic Sea basin, Ecol. Modell., 227, 117-135, 2012.

Humborg, C., Danielsson, A., Sjöberg, B., and Green, M.: Nutrient land-sea fluxes in oligothrophic and pristine estuaries of the Gulf of Bothnia, Baltic Sea, Estuar. Coast. Shelf Sci., 56, 781-793, 2003.

Jackson, A. L., Inger, R., Bearhop, S., and Parnell, A.: Erroneous behaviour of MixSIR, a recently published Bayesian isotope mixing model: a discussion of Moore \& Semmens (2008), Ecol. Lett., 12, E1-5, 2009.

Jäntti, H., Stange, F., Leskinen, E., and Hietanen, S.: Seasonal variation in nitrification and nitrate-reduction pathways in coastal sediments in the Gulf of Finland, Baltic Sea, Aquat. Microb. Ecol., 63, 171-181, 2011.

Johannsen, A., Dähnke, K., and Emeis, K.: Isotopic composition of nitrate in five German rivers discharging into the North Sea, Org. Geochem., 39, 1-12, 2008.

Kendall, C.: Tracing nitrogen sources and cycling in catchments, in Isotope tracers in catchment hydrology, edited by: Kendall, C. and McDonnell, J. J., Elsevier, Amsterdam., 521-576, 1998

Kendall, C., Elliott, E., and Wankel, S.: Tracing anthropogenic inputs of nitrogen to ecosystems, in Stable isotopes in ecology, edited by: Michener, K. L. R. H., Blackwell Publishing, 375449, 2007

Kim, T.-W., Lee, K., Najjar, R. G., Jeong, H.-D., and Jeong, H. J.: Increasing $\mathrm{N}$ abundance in the northwestern Pacific Ocean due to atmospheric nitrogen deposition., Science, 334, 505-9, 2011.

Knapp, A. N., Sigman, D. M., and Lipschultz, F.: N isotopic composition of dissolved organic nitrogen and nitrate at the Bermuda Atlantic Time-series Study site, Global Biogeochem. Cy., 19, 115, 2005.

Korth, F., Fry, B., Liskow, I., and Voss, M.: Nitrogen turnover during the spring outflows of the nitrate-rich Curonian and Szczecin lagoons using dual nitrate isotopes, Mar. Chem., 154, 1-11, 2013.

Koszelnik, P. and Gruca-Rokosz, R.: Determination of nitrate isotopic signature in waters of different sources by analysing the nitrogen and oxygen isotopic ratio, Environ. Sci. Process. Impacts, 15, 751-759, 2013.

Lääne, A., Kraav, E., and Titova, G.: Baltic Sea, GIWA regional assessment 17, University of Kalmar on behalf of United Nations Environment Programme, Kalmar, Sweden, 2005.

Liu, K.-K., Su, M.-J., Hsueh, C.-R., and Gong, G.-C.: The nitrogen isotopic composition of nitrate in the Kuroshio Water northeast of Taiwan: evidence for nitrogen fixation as a source of isotopically light nitrate, Mar. Chem., 54, 273-292, 1996.

Lunau, M., Voss, M., Erickson, M., Dziallas, C., Casciotti, K., and Ducklow, H.: Excess nitrate loads to coastal waters reduces nitrate removal efficiency: mechanism and implications for coastal eutrophication., Environ. Microbiol., 15, 1492-504, 2013.

Lundberg, C., Lönnroth, M., von Numers, M., and Bonsdorff, E.: A multivariate assessment of coastal eutrophication. Examples from the Gulf of Finland, northern Baltic Sea, Mar. Pollut. Bull., 50, 1185-1196, 2005.

Lundberg, C., Jakobsson, B. M., and Bonsdorff, E.: The spreading of eutrophication in the eastern coast of the Gulf of Both- nia, northern Baltic Sea - An analysis in time and space, Estuar. Coast. Shelf Sci., 82, 152-160, 2009.

Mayer, B., Boyer, E. W., Goodale, C., Jaworski, N. A., Breemen, N. van, Howarth, R. W., Seitzinger, S., Billen, G., Lajtha, K., Nadelhoffer, K., Dam, D. van, Hetling, L. J., Nosal, M., and Paustian, K.: Sources of nitrate in rivers draining sixteen watersheds in the northeastern US: Isotopic constraints, Biogeochemistry, 57/58, 171-197, 2002.

Michaels, A. F., Siegel, D. A., Johnson, R. J., Knap, A. H., and Galloway, J. N.: Episodic inputs of atmospheric nitrogen to the sargasso sea: contributions to new production and phytoplankton blooms, Global Biogeochem. Cy., 7, 339-351, 1993.

Montoya, J., Carpenter, E., and Capone, D.: Nitrogen fixation and nitrogen isotope abundances in zooplankton of the oligotrophic North Atlantic, Limnol. Oceanogr., 47, 1617-1628, 2002.

Moore, J. W. and Semmens, B. X.: Incorporating uncertainty and prior information into stable isotope mixing models, Ecol. Lett., 11, 470-80, 2008.

Mulholland, P. J., Helton, A. M., Poole, G. C., Hall, R. O., Hamilton, S. K., Peterson, B. J., Tank, J. L., Ashkenas, L. R., Cooper, L. W., Dahm, C. N., Dodds, W. K., Findlay, S. E. G., Gregory, S. V, Grimm, N. B., Johnson, S. L., McDowell, W. H., Meyer, J. L., Valett, H. M., Webster, J. R., Arango, C. P., Beaulieu, J. J., Bernot, M. J., Burgin, A. J., Crenshaw, C. L., Johnson, L. T., Niederlehner, B. R., O'Brien, J. M., Potter, J. D., Sheibley, R. W., Sobota, D. J., and Thomas, S. M.: Stream denitrification across biomes and its response to anthropogenic nitrate loading, Nature, 452, 202-5, 2008.

Myrberg, K. and Andrejev, O.: Modelling of the circulation, water exchange and water age properties of the Gulf of Bothnia, Oceanologia, 48, 55-74, 2006.

Nestler, A., Berglund, M., Accoe, F., Duta, S., Xue, D. M., Boeckx, P., and Taylor, P.: Isotopes for improved management of nitrate pollution in aqueous resources: review of surface water field studies, Environ. Sci. Pollut. Res., 18, 519-533, 2011.

Neumann, T.: Towards a 3-D-ecosystem model of the Baltic Sea, J. Mar. Syst., 25, 405-419, 2000.

Pagenkopf, W.: Aktuelle Nährstoffbilanzierung für Teilgebiete des Einzugsgebiets der Warnow, Geodaten Integration \& Analyse, Berlin, 2001.

Parnell, A. C., Inger, R., Bearhop, S., and Jackson, A. L.: Source partitioning using stable isotopes: coping with too much variation, PLoS One, 5, e9672, doi:10.1371/journal.pone.0009672, 2010.

Pfenning, K. and McMahon, P.: Effect of nitrate, organic carbon, and temperature on potential denitrification rates in nitrate-rich riverbed sediments, J. Hydrol., 187, 283-295, 1997.

Pilkaityté, R. and Razinkovas, A.: Factors controlling phytoplankton blooms in a temperate estuary: nutrient limitation and physical forcing, Hydrobiologia, 555, 41-48, 2006.

Radtke, H., Neumann, T., Voss, M., and Fennel, W.: Modeling pathways of riverine nitrogen and phosphorus in the Baltic Sea, J. Geophys. Res., 117, C09024, doi:10.1029/2012JC008119, 2012.

Schernewski, G. and Neumann, T.: The trophic state of the Baltic Sea a century ago: a model simulation study, J. Mar. Syst., 53, 109-124, 2005.

Sferratore, A., Billen, G., Garnier, J., Smedberg, E., Humborg, C., and Rahm, L.: Modelling nutrient fluxes from sub-arctic basins: 
Comparison of pristine vs. dammed rivers, J. Mar. Syst., 73, 236249, 2008.

Sigman, D. M., Altabet, M. A., Mccorkle, D. C., Francois, R., and Fischer, G.: The d15N of nitrate in the Southern Ocean?: Nitrogen cycling and circulation in the ocean interior, J. Geophys. Res., 105, 19599-19614, 2000.

Sigman, D. M., Casciotti, K. L., Andreani, M., Barford, C., Galanter, M., and Böhlke, J. K.: A Bacterial Method for the Nitrogen Isotopic Analysis of Nitrate in Seawater and Freshwater, Anal. Chem., 73, 4145-4153, 2001.

Sigman, D. M., DiFiori, P. J., Hain, M. P., Deutsch, C., Wang, Y., Karl, D. M., Knapp, A. N., Lehmann, M. F., and Pantoja, S.: The dual isotopes of deep nitrate as a constraint on the cycle budget of oceanic fixed nitrogen, Deep Sea Res. Pt. I, 56, 1419-1439, 2009.

Silva, S. R., Kendall, C., Wilkison, D. H., Ziegler, A. C., Chang, C. C. Y., and Avanzino, R. J.: A new method for collection of nitrate from fresh water and the analysis of nitrogen and oxygen isotope ratios, J. Hydrol., 228, 22-36, 2000.

Spokes, L., Jickells, T., Weston, K., Gustafsson, B. G., Johnsson, M., Liljebladh, B., Conley, D., Ambelas-Skjødth, C., Brandt, J., Carstensen, J., Christiansen, T., Frohn, L., Geernaert, G., Hertel, O., Jensen, B., Lundsgaard, C., Markager, S., W. Martinsen, Møller, B., Pedersen, B., Sauerberg, K., Sørensen, L.L., Hasager, C.C., Sempreviva, A. M., Pryor, S. C., Lund, S. W., Larsen, S., Tjernström, M., Svensson, G., and Zagar, M.: MEAD: An interdisciplinary study of the marine effects of atmospheric deposition in the Kattegat, Environ. Pollut., 140, 1453-1462, 2006.

Stal, L. J., Albertano, P., Bergman, B., von Bröckel, K., Gallon, J. R., Hayes, P. K., Sivonen, K., and Walsby, A. E.: BASIC: Baltic Sea Cyanobacteria. An investigation of the structure and dynamics of water blooms of cyanobacteria in the Baltic Sea - Responses to a changing environment, Cont. Shelf Res., 23, 16951714, 2003.

Stålnacke, P., Grimvall, A., Sundblad, K., and Tonderski, A.: Estimation of riverine loads of nitrogen and phosphorus to the Baltic Sea, 1970-1993, Environ. Monit. Assess., 58, 173-200, 1999.

Stepanauskas, R., Jorgensen, N. O. G., Eigaard, O. R., Žvikas, A., Tranvik, L. J., and Leonardson, L.: Summer Inputs of Riverine Nutrients to the Baltic Sea: Bioavailability and Eutrophication Relevance, Ecol. Monogr., 72, 579-597, 2002.

Thunell, R. C., Sigman, D. M., Muller-Karger, F., Astor, Y., and Varela, R.: Nitrogen isotope dynamics of the Cariaco Basin, Venezuela, Global Biogeochem. Cy., 18, 1-13, 2004.

Vahtera, E., Laanemets, J., Pavelson, J., Huttunen, M., and Kononen, K.: Effect of upwelling on the pelagic environment and bloom-forming cyanobacteria in the western Gulf of Finland, Baltic Sea, J. Mar. Syst., 58, 67-82, 2005.
Vahtera, E., Conley, D. J., Gustafsson, B. G., Kuosa, H., Pitkänen, H., Savchuk, O. P., Tamminen, T., Viitasalo, M., Voss, M., Wasmund, N., and Wulff, F.: Internal ecosystem feedbacks enhance nitrogen-fixing cyanobacteria blooms and complicate management in the Baltic Sea, Ambio, 36, 186-94, 2007.

Villnäs, A., Norkko, J., Hietanen, S., Josefson, A., Lukkari, K., and Norkko, A.: The role of recurrent disturbances for ecosystem multifunctionality, Ecology, 94, 2275-2287, 2013.

Vitousek, P. M., Aber, J. D., Howarth, R. W., Likens, G. E., Matson, P. A., Schindler, D. W., Schlesinger, W. H., and Tilman, D. G.: Human alteration of the global nitrogen cycle: Sources and consequences, Ecol. Appl., 7, 737-750, 1997.

Voss, M., Emeis, K.-C., Hille, S., Neumann, T., and Dippner, J. W.: Nitrogen cycle of the Baltic Sea from an isotopic perspective, Global Biogeochem. Cy., 19, 1-15, 2005.

Voss, M., Deutsch, B., Elmgren, R., Humborg, C., Kuuppo, P., Pastuszak, M., Rolff, C., and Schulte, U.: Source identification of nitrate by means of isotopic tracers in the Baltic Sea catchments, Biogeosciences, 3, 663-676, doi:10.5194/bg-3-663-2006, 2006.

Voss, M., Dippner, J. W., Humborg, C., Hürdler, J., Korth, F., Neumann, T., Schernewski, G., and Venohr, M.: History and scenarios of future development of Baltic Sea eutrophication, Estuar. Coast. Shelf Sci., 92, 307-322, 2011.

Wankel, S. D., Kendall, C., Francis, C. A., and Paytan, A.: Nitrogen sources and cycling in the San Francisco Bay Estuary: A nitrate dual isotopic composition approach, Limnol. Ocean., 51, 16541664, 2006.

Wasmund, N., Voss, M., and Lochte, K.: Evidence of nitrogen fixation by non-heterocystous cyanobacteria in the Baltic Sea and re-calculation of a budget of nitrogen fixation, Mar. Ecol. Prog. Ser., 214, 1-14, 2001.

Wulff, F., Humborg, C., Medina, M. R., Mörth, C.-M., Savchuk, O., and Sokolov, A.: Revision of the country allocation of nutrient reductions in the Baltic Sea Action Plan, Baltic Nest Institute, Stockholm, 2009.

Xue, D., De Baets, B., Van Cleemput, O., Hennessy, C., Berglund, M., and Boeckx, P.: Use of a Bayesian isotope mixing model to estimate proportional contributions of multiple nitrate sources in surface water, Environ. Pollut., 161, 43-9, 2012.

Xue, D., De Baets, B., Van Cleemput, O., Hennessy, C., Berglund, M., and Boeckx, P.: Classification of Nitrate Polluting Activities through Clustering of Isotope Mixing Model Outputs, J. Environ. Qual., 42, 1486-97, 2013.

Yang, L., Han, J., Xue, J., Zeng, L., Shi, J., Wu, L., and Jiang, Y.: Nitrate source apportionment in a subtropical watershed using Bayesian model, Sci. Total Environ., 463/464, 340-7, 2013. 